Original Research

\title{
Accumulation of Heavy Metals in Bottom Sediments of Baltic Sea Catchment Rivers Affected by Operations of Petroleum and Natural Gas Mines in Western Pomerania, Poland
}

\author{
Magdalena Senze*, Monika Kowalska-Góralska, Przemysław Pokorny, \\ Wojciech Dobicki, Ryszard Polechoński \\ Wrocław University of Environmental and Life Sciences, \\ Chełmońskiego 38C, 51-630 Wroclaw, Poland \\ Received: February 9, 2015 \\ Accepted: April 1, 2015
}

\begin{abstract}
Our study was conducted in the area of the Parseta and Radew rivers in 2012 and 2013. Samples were taken of water and bottom sediments. In terms of their physico-chemical composition, the tested waters can be characterized as slightly polluted. In terms of zinc and copper concentrations, the waters belong to purity class I, but the contents of cadmium, lead, and nickel exceed the Proposed Environmental Quality Standards for Priority Substances.

As far as copper, nickel, zinc, and cadmium are concerned, the studied sediments were not polluted, and the geo-chemical index values were within class I. The relevant accumulation rates for metals in sediments can be ordered as follows: $\mathrm{Cd}<\mathrm{Ni}<\mathrm{Pb}<\mathrm{Cu}<\mathrm{Zn}$.

The studied parameters changed (in both rivers) according to how far down the stream samples were taken. The sites nearest the Petroleum and Natural Gas Mine at Karlino had the highest concentrations of all the metals in question. Further down the stream the values fell and the river water self-purification process was evident. It is encouraging to see that despite a clear impact of the operation of the mine on the examined water quality, the aquatic environment seems not only able to absorb pollutants, but also to recover over a relatively short section of the river.
\end{abstract}

Keywords: heavy metals, water, accumulation, rivers, sediments

\section{Introduction}

Environmental pollution influences all environmental components: air, precipitation, surface water, groundwater, and soil. Between these elements constant exchange and penetration by chemicals occurs. Their sources are natural and anthropogenic. The quantity and quality of these contaminants are varied and depend on a number of factors.

*e-mail: magdalena.senze@up.wroc.pl
Respect for its natural geographical location, terrain, geological structure, the presence of water reservoirs, and open spaces is important. The distortion of the natural landscape by people introduces more or less visible changes. However, they are not neutral to the environment. These changes result in alterations to the composition of air, water, and soil. This is done both at a low and a high degree of contamination and reduces the accumulation of chemical condition of the environment. 
The natural environment of surface waters absorbs pollutants in various ways from direct and indirect catchments. Of great importance are the inflows from the point sources, area runoff, and both dry and wet precipitation. Rivers, which act as pollution receivers, often flow through areas with various degrees of anthropopression.

This is reflected in the quality of water and bottom sediment, whose image shows the situation in the basin. Generally, mountain rivers carry water of good quality. Their pollution comes only from precipitation and inflows mostly natural ingredients. In the lower parts of the mountainous areas, depending on the type of natural water catchment and sediment composition, contamination is enriched by products of anthropogenic origin. Here agricultural, municipal, and economic impact begins to be visible. The closer to the estuary of the river, the more rich the products of different origins. But not all rivers in Poland have sources in the mountains. The coastal rivers have ones located in the lowlands, but this area is hilly and was created during the Ice Age. This area is covered by forests, fields, and meadows, and some rivers have lakes as sources.

The medium-sized rivers in the coastal belt in Poland most often collect products of agricultural or municipal origin. Occasionally they are near point sources of pollution, which may exert a potentially stronger influence on the results of assessments of ecological conditions. Therefore, a good indicator of ecological status is the monitoring of pollutants accumulating in sediments.

The purpose of this study was to assess a mine's impact on the quality of aquatic environments of the Radew and Parseta rivers by determining metal accumulation in bottom sediments.

\section{Materials and Methods}

\section{Study Area and Samplings}

The study was conducted in the area of the Parseta and Radew rivers in Poland's Western Pomerania region. The Parseta's sources are located near Parsecko in the Drawskie Lake District, near Szczecinek. Near the village of Pustary, the river enters the Koszalinskie Coast and at Kolobrzeg flows into the Baltic. The river is $139 \mathrm{~km}$ long, its catchment area is $3,151 \mathrm{~km}^{2}$, and its principal (right) tributary is the Radew River, which flows into the Parseta at Karlino. The river flows through the towns of Bialogard, Karlino, and Kolobrzeg, of about 100,000 inhabitants, plus the villages of Cybulino, Kurowo, Mostowo, Rosnowo, Niedalino, Białogorzyno, Nosowko, Nosowo, Parsowo, and Karlinko. The number of inhabitants in all the basin of the Parseta is about 130,000.

Three small hydropower stations have been constructed on the river: at Roscino $(53.0 \mathrm{~km})$, Storkowo $(116.3 \mathrm{~km})$, and Pustkowo $(121.2 \mathrm{~km})$. The river is administered by the Regional Water Management Board (RZGW) in Szczecin, which established a fishing district that covers the water from the river source to the border between inland waters and internal sea waters. The Parseta River Valley forms part of the
Parseta River Catchment, a special habitat protection zone. A canoeing route also has been established on the river [1].

The Radew River is a right tributary of the Parseta. The Radew is $83 \mathrm{~km}$ long and its catchment area is 1,091.5 $\mathrm{km}^{2}$. Its source is near the village of Zydowo in the Bytowskie Lake District. The river flows through only one town, Karlino with about 9,000 inhabitants, and 10 villages: Zabiniec, Bobrowo, Mostowo, Rosnowo, Niedalino, Wronie Gniazdo, Bialogorzyno, Nosowo, and Parsowo. The number of inhabitants in all the basin of the Radew is about 30,000. The river flows into the Parseta at Karlino. Its left-hand tributaries include the Chociel, Biblical, and Chotla, and its right-hand one is the Czarna. Three small hydropower stations were built on the river: at Rosnowo $(44.7 \mathrm{~km})$, Niedalino $(36.0 \mathrm{~km})$, and Karlino $(0.53 \mathrm{~km})$. The river valley is part of the Dolina Radwi protected landscape area (the Radew Valley), and the Natura 2000 network of the Radew, Choices, and Chotla river valleys. A canoeing route has been created between Żydowo and Karlino [1].

Both the Parseta and the Radew flow near the Polish Oil and Gas Company of Warsaw petroleum and natural gas mine located at the settlement of Krzywoploty, just outside of Karlino. In line with the establishment's policy, the mine takes care to pro-ecologically manage local off-balance resources and high-energy waste gases. Thanks to such an approach, solid fuel is converted into gas fuel and, at the same time, the amount of pollutants is limited by nearly $80 \%$. One of the priority considerations of the mine at Karlino is to provide natural gas to the commune on a constant basis [1]. The mine at Karlino is $0.30 \mathrm{~km}$ from the Radew River and $4 \mathrm{~km}$ from the Parseta.

The area lines of the Parseta River are between latitude $53^{\circ} 43^{\prime} 12.471^{\prime \prime}-54^{\circ} 10^{\prime} 39.9451^{\prime \prime} \mathrm{N}$, and longitude $15^{\circ} 33^{\prime} 40.3112^{\prime \prime}-16^{\circ} 34^{\prime} 49.8821^{\prime \prime}$ E. For the Radew the area lines are $54^{\circ} 1$ '54.6652'-54'2'59.2585" N and $15^{\circ} 52$ '32.2206" $-16^{\circ} 35^{\prime} 50.2125^{\prime \prime}$ E (Fig. 1). The study material consisted of water and bottom sediments sampled from the Radew (nine sites) and the Parseta (nine sites) in July 2012 and July 2013 (Fig. 2).

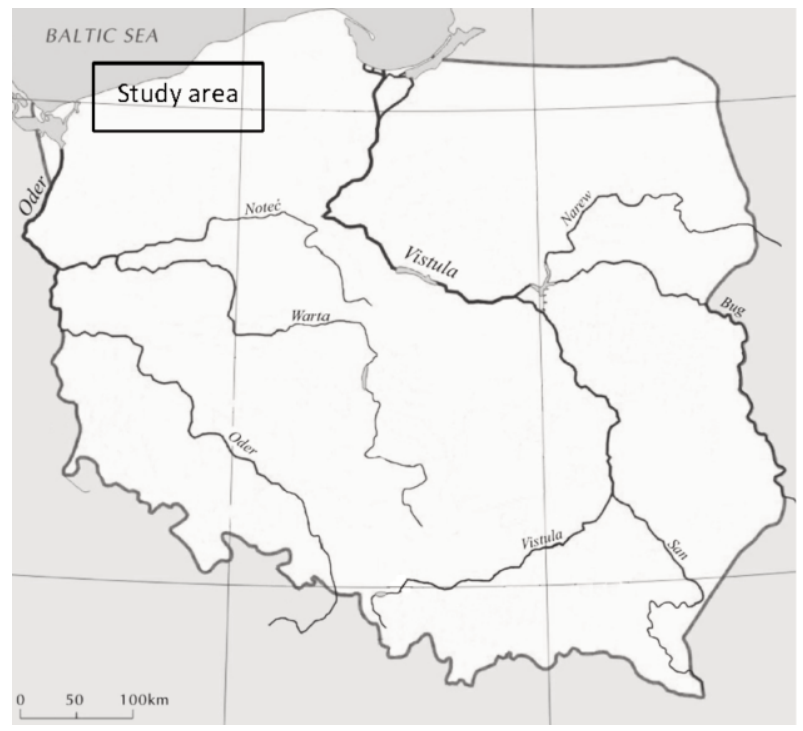

Fig. 1. Study area. 


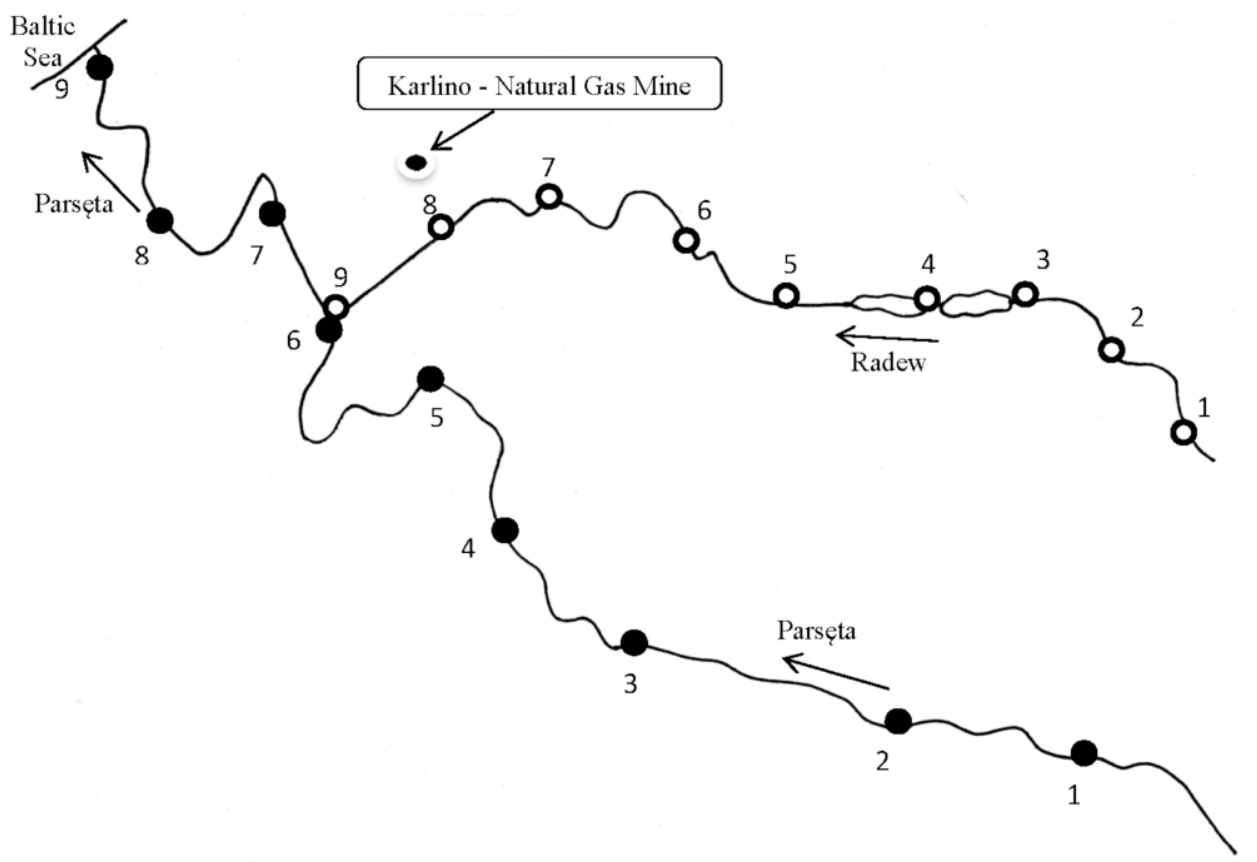

Fig. 2. Locations of sampling sites.

Parseta research sites are:

1. Storkowo (N:5345' 58.37"; E:16³0' 55.05")

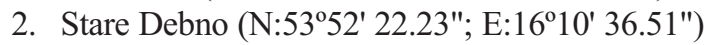

3. Osowko (N:5353' 49.92"; E:16 $\left.{ }^{\circ} 5^{\prime} 11.14^{\prime \prime}\right)$

4. Byszyno (N:5356' 56.88"; E:1603' 4.45")

5. Bialogard (N:540' 8.69"; E: $\left.15^{\circ} 58^{\prime} 48.61^{\prime \prime}\right)$

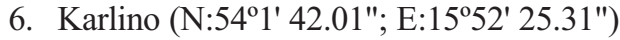

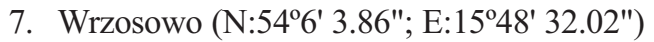

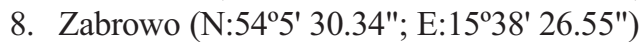

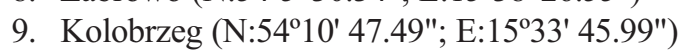
Radew research sites are:

1. Cybulino (N:54²' 19.87"; E:16³7' 8.31")

2. Kurowo (N:54³' 3.95"; E:16³4' 55.44")

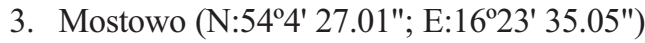

4. Rosnowo (N:54² $\left.4^{\prime} 28.01^{\prime \prime} ; \mathrm{E}: 16^{\circ} 17^{\prime} 43.76^{\prime \prime}\right)$

5. Niedalino (N:54²3' 40.36"; E:16 $\left.{ }^{\circ} 10^{\prime} 1.65^{\prime \prime}\right)$

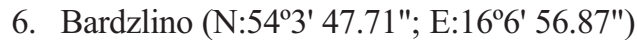

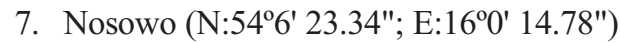

8. Karlinko (N:54²' 42.21"; E: $15^{\circ} 54^{\prime}$ 2.68")

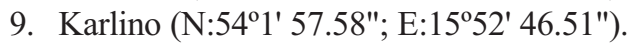

\section{Collection and Treatment of Samples}

Water was sampled into polyethylene bottles by means of a $2 \mathrm{dm}^{3}$ sampler, and then filtered using 0.45 Whatman 1 filters. The water reaction was determined by means of the potentiometer method ( $\mathrm{pH}$ meter $\mathrm{pH} 207$ Slandi), electrolytic conductivity by means of the conducto-metric method (konduktometr CM 204 Slandi), total hardness using EDTA titration, alkalinity to methyl orange, calcium by EDTA titration, magnesium by means of the calculation method, and chlorides using the Mohr method [2-7].

Water samples for determining metal concentrations were prepared by thickening in a water bath with concentrated $\mathrm{HNO}_{3}$. Afterward the resulting products were cooled to room temperature and diluted with distilled water to obtain a volume of $25 \mathrm{~cm}^{3}$.

Sediment samples were dried at room temperature, pounded, and sieved through a $0.2 \mathrm{~mm}$ mesh sieve, then 2.0 $\mathrm{g}$ of air-dry, homogenised material was put into an HP 500 teflon vessel. After adding $10 \mathrm{~cm}^{3}$ of $\mathrm{HNO}_{3}: \mathrm{HClO}_{4}(3: 1)$ (Sigma-Aldrich) to the sample, it was left at room temperature for 24 hours. Next, it was placed in a CEM Mars 5 microwave oven and mineralised using the three-level mineralisation process. After being cooled to room temperature, the mineralisation products were transferred to test tubes and diluted with distilled water up to $25 \mathrm{~cm}^{3}$.

Metal $(\mathrm{Cu}, \mathrm{Ni}, \mathrm{Cd}, \mathrm{Pb}, \mathrm{Zn})$ contents in water and bottom sediments were determined using atomic absorption spectrophotometry by means of a Varian Spectra AA110/220 unit (PB 10/I) [8].

The $C F$ metal accumulation rate was determined as a ratio of metal contents in bottom sediment $C_{M O}$ to metal concentrations in water $C_{M W}[9]$.

$$
C F=\frac{C_{M O}}{C_{M W}}
$$

The sediment pollution with heavy metals was determined using geo-accumulation index $I_{\text {geo }}$ and in line with the geo-chemical purity classes of bottom sediments $[10,11]$.

$I_{\text {geo }}$ was calculated using the following formula:

$$
I_{\text {geo }}=\log _{2}\left[M_{o} /\left(1.5 \cdot M_{t}\right)\right]
$$

...where $M_{o}$ is the metal concentration in the sediment and $M_{t}$ is the geo-chemical background of the metal.

The geo-accumulation index has seven degrees of sediment purity, from non-polluted sediments to heavily polluted ones (Table 1). 
Table 1. The values of geo-accumulation index $\left(I_{\text {geo }}\right)$ in relation to levels of contamination [11].

\begin{tabular}{|c|c|c|}
\hline $\begin{array}{c}\text { Range of } \\
\text { values } I_{\text {geo }}\end{array}$ & Degree & Pollution status \\
\hline$<0$ & 0 & Unpolluted \\
\hline $0-1$ & 1 & Unpolluted to moderately polluted \\
\hline $1-2$ & 2 & Moderately polluted \\
\hline $2-3$ & 3 & Moderately to strongly polluted \\
\hline $3-4$ & 4 & Strongly polluted \\
\hline $4-5$ & 5 & Strongly to extremely strongly polluted \\
\hline$<5$ & 6 & Extremely polluted \\
\hline
\end{tabular}

All calculations were made using Statistica 10. Results are expressed as arithmetic means and standard deviation (SD). Comparisons between groups were made using the unpaired Student's t-test. Differences with $\mathrm{p}<0.05$ were considered statistically significant.

\section{Results}

The reaction of the water samples from the Parseta and the Radew ranged from slightly acidic to neutral. Water alkalinity oscillated between $160.13 \mathrm{mgCaCO}_{3} \cdot \mathrm{dm}^{-3}$ and $280.22 \mathrm{mgCaCO}_{3} \cdot \mathrm{dm}^{-3}$ (Table 2). The studied waters were medium hard $\left(174.93-249.90 \mathrm{mgCaCO}_{3} \cdot \mathrm{dm}^{-3}\right)$. Calcium concentrations in the Parseta were higher than those in the Radew. Magnesium contents ranged from $3.47 \mathrm{mgMg} \cdot \mathrm{dm}^{-3}$ to $16.49 \mathrm{mgMg} \cdot \mathrm{dm}^{-3}$. Water mineralisation, expressed as electrolytic conductivity, amounted to $574 \mu \mathrm{S} \cdot \mathrm{cm}^{-1}$, and so was typical of water with a medium degree of pollution. Chloride concentrations fell within the range of 16.00 $\mathrm{mgCl} \cdot \mathrm{dm}^{-3}-46.00 \mathrm{mgCl} \cdot \mathrm{dm}^{-3}$.

Nickel concentrations in the water samples from the Parseta and the Radew were from $0.0028 \mathrm{mgNi} \cdot \mathrm{dm}^{-3}$ to
$0.0525 \mathrm{mgNi} \cdot \mathrm{dm}^{-3}$ (Table 3). Cadmium concentrations ranged from $0.0007 \mathrm{mgCd} \cdot \mathrm{dm}^{-3}$ to $0.0119 \mathrm{mgCd} \cdot \mathrm{dm}^{-3}$, and lead concentrations from $0.0754 \mathrm{mgPb} \cdot \mathrm{dm}^{-3}$ to 0.1125 $\mathrm{mgPb} \cdot \mathrm{dm}^{-3}$. Zinc concentrations in water were from 0.0106 $\mathrm{mgZn} \cdot \mathrm{dm}^{-3}$ to $0.0620 \mathrm{mgZn} \cdot \mathrm{dm}^{-3}$. Copper contents in river water oscillated between $0.0026 \mathrm{mgCu} \cdot \mathrm{dm}^{-3}$ and 0.0390 $\mathrm{mgCu} \cdot \mathrm{dm}^{-3}$. Within two years of research in water of Parseta and Radew rivers the same level of lead remained. The concentrations of nickel, copper, and cadmium were higher in 2012 and zinc in 2013.

Heavy metal concentrations in bottom sediments of the two rivers were comparable, with the values ranging, in the case of nickel, from 0.558 to $7.568 \mathrm{mgNi} \cdot \mathrm{kg}^{-1}$, lead from 2.543 to $17.5705 \mathrm{mgPb} \cdot \mathrm{kg}^{-1}$, cadmium from 0.002 to 1.005 $\mathrm{mgCd} \cdot \mathrm{kg}^{-1}$, zinc from 3.708 to $50.565 \mathrm{mgZn} \cdot \mathrm{kg}^{-1}$, and copper from 0.175 to $8.429 \mathrm{mgCu} \cdot \mathrm{kg}^{-1}$ (Table 3).

Alongside the Radew in localities below sources, low levels of metals in water and sediments were noted. Only in the middle of the river, in sites located near Rosnowo and Mostowo villages did metal levels increase. On the following sites decreasing amounts of metals were noted. Higher levels were recorded in Karlino next to the mine oil and gas. However, at the estuary in Karlino metals levels were again lower.

In the water of the Parseta higher metal concentrations were noted only in the middle course of the river, mainly in Karlino. Below this site levels of metals were lower. The high metals content in sediments occurred below the sources, then along the course of the river followed lower level and rising again below Karlino and Kolobrzeg.

In both rivers metal levels were higher in the second year of the study. The biggest differences were related to nickel and cadmium, and the smallest to lead.

The metal accumulation rate for bottom sediments (CF) was calculated for all metals. The highest values were recorded for zinc $(\mathrm{CF}=164.51-2,206.66)$, and the lowest for lead $(\mathrm{CF}=26.85-178.92)$ (Table 3$)$. The accumulation rates can be arranged in diminishing order as: $\mathrm{Zn}<\mathrm{Ni}<\mathrm{Cu}<\mathrm{Cd}<\mathrm{Pb}$ (the Parseta) and $\mathrm{Zn}<\mathrm{Cu}<\mathrm{Ni}<\mathrm{Cd}<\mathrm{Pb}$ (the Radew).

Table 2. The physic-chemical parameters of Parseta and Radew river waters.

\begin{tabular}{|l|c|c|}
\hline \multirow{2}{*}{\multicolumn{1}{|c|}{ Parameters }} & \multicolumn{2}{c|}{ min-max $(\bar{x} \pm \mathrm{SD})$} \\
\cline { 2 - 3 } & \multicolumn{2}{|c|}{ Radew River } \\
\hline Reaction $(\mathrm{pH})$ & $6.66-7.62$ & $6.66-7.62$ \\
\hline Electrolytic conductivity $\left(\mu \mathrm{S} \cdot \mathrm{cm}^{-1}\right)$ & $429.00-574.00(485.83 \pm 44.63)$ & $340.00-434.00(394.67 \pm 29.51)$ \\
\hline Alkalinity $\left(\mathrm{mgCaCO}{ }_{3} \cdot \mathrm{dm}^{-3}\right)$ & $200.16-280.22(229.63 \pm 22.89)$ & $160.13-240.19(197.38 \pm 17.44)$ \\
\hline Total hardness $\left(\mathrm{mgCaCO}_{3} \cdot \mathrm{dm}^{-3}\right)$ & $196.35-249.90(225.31 \pm 12.66)$ & $174.93-214.20(197.34 \pm 13.51)$ \\
\hline Calcium $\left(\mathrm{mgCa} \cdot \mathrm{dm}^{-3}\right)$ & $67.21-81.51(72.45 \pm 3.89)$ & $55.77-71.50(61.25 \pm 4.39)$ \\
\hline Magnesium $\left(\mathrm{mgMg} \cdot \mathrm{dm}^{-3}\right)$ & $3.47-13.89(10.51 \pm 3.06)$ & $6.77-16.49(10.84 \pm 3.33)$ \\
\hline Chlorides $\left(\mathrm{mgCl} \cdot \mathrm{dm}^{-3}\right)$ & $16.00-46.00(27.33 \pm 9.51)$ & $16.00-34.00(22.67 \pm 4.70)$ \\
\hline
\end{tabular}


Table 3. Mean, minimum, and maximum heavy metals concentrations in sediments $\left(\mathrm{mg} \cdot \mathrm{kg}^{-1}\right.$, dry weight $)$ and water $\left(\mathrm{mg} \cdot \mathrm{dm}^{-3}\right)$, and accumulation coefficient (CF).

\begin{tabular}{|c|c|c|c|c|c|c|}
\hline \multirow{2}{*}{ River } & \multirow{2}{*}{ Material } & $\mathrm{Ni}$ & $\mathrm{Cd}$ & $\mathrm{Pb}$ & $\mathrm{Zn}$ & $\mathrm{Cu}$ \\
\hline & & \multicolumn{5}{|c|}{$\min -\max (\bar{x} \pm \mathrm{SD})$} \\
\hline \multirow{5}{*}{ Parseta } & \multirow{2}{*}{ Sediments } & $1.363-7.568$ & $0.005-0.697$ & $2.543-17.571$ & $4.874-30.866$ & $0.470-7.366$ \\
\hline & & $(2.951 \pm 1.57)$ & $(0.210 \pm 0.20)$ & $(6.578 \pm 3.81)$ & $(12.108 \pm 7.29)$ & $(2.101 \pm 2.10)$ \\
\hline & \multirow{2}{*}{ Water } & $0.0028-0.0477$ & $0.0007-0.0119$ & $0.0754-0.1125$ & $0.0106-0.0258$ & $0.0030-0.0390$ \\
\hline & & $(0.0246 \pm 0.02)$ & $(0.0060 \pm 0.01)$ & $(0.0926 \pm 0.01)$ & $(0.0171 \pm 0.01)$ & $(0.0130 \pm 0.01)$ \\
\hline & $\mathrm{CF}$ & $\begin{array}{c}31.12-1681.84 \\
(455.17 \pm 524.41)\end{array}$ & $\begin{array}{c}0.45-629.50 \\
(159.51 \pm 192.50)\end{array}$ & $\begin{array}{c}26.85-178.92 \\
(72.28 \pm 42.43)\end{array}$ & $\begin{array}{l}329.85-2206.66 \\
(732.73 \pm 471.09)\end{array}$ & $\begin{array}{c}25.98-2455.33 \\
(402.38 \pm 425.53)\end{array}$ \\
\hline \multirow{6}{*}{ Radew } & \multirow{2}{*}{ Sediments } & $0.558-7.479$ & $0.002-1.005$ & $3.171-14.133$ & $3.708-50.565$ & $0.175-8.429$ \\
\hline & & $(3.050 \pm 2.10)$ & $(0.265 \pm 0.32)$ & $(6.355 \pm 2.83)$ & $(15.411 \pm 13.48)$ & $(2.605 \pm 2.75)$ \\
\hline & \multirow{2}{*}{ Water } & $0.0042-0.0525$ & $0.0011-0.0116$ & $0.0754-0.1064$ & $0.0128-0.0620$ & $0.0026-0.0202$ \\
\hline & & $(0.0249 \pm 0.02)$ & $(0.0059 \pm 0.01)$ & $(0.0895 \pm 0.01)$ & $(0.0215 \pm 0.01)$ & $(0.0113 \pm 0.01)$ \\
\hline & \multirow{2}{*}{$\mathrm{CF}$} & $10.64-1087.49$ & $0.23-656.93$ & $35.75-165.88$ & $164.51-1998.63$ & $9.64-2955.19$ \\
\hline & & $(379.24 \pm 395.21)$ & $(171.62 \pm 220.28)$ & $(71.25 \pm 32.01)$ & $(759.67 \pm 589.01)$ & $(638.43 \pm 915.11)$ \\
\hline
\end{tabular}

The greatest accumulation of metals in the bottom sediments of the river Parseta were found in three areas: below sources, and in the areas of Karlino and Kolobrzeg. In the Radew the largest accumulations occurred in Nosowo, Rosnowo, and Karlino.

There is not a statistically significant difference between the means of the Parseta and Radew $(\mathrm{p}<0.05)$ confidence level: $\mathrm{Ni}, \mathrm{Cd}, \mathrm{Pb}$, and $\mathrm{Zn}$.

\section{Discussion}

The water in the rivers studied composition characterized by a typical surface water flowing lowland areas of Pomerania. A moderate load of minerals and $\mathrm{pH}$ in the range of neutral tend to apply for a moderate level of pollution in the waters.

The studied waters meet the criteria set for surface water in the relevant Directive of the European Parliament and of the Council (2008/105/EC), and in line with the Polish classification system for surface waters, as they belong to class II waters $[8,12,13]$. As far as substances particularly harmful to aquatic environments are concerned, zinc and copper concentrations in the water were within the border values set for water quality class I. However, cadmium, lead, and nickel concentrations exceeded the Proposed Environmental Quality Standards for Priority Substances $[12,13]$.

The concentrations of nickel in the waters of the Parseta and the Radew were higher than those given in the literature on the subject with the exception of English, German, and Turkish rivers $[28,30,31]$. The content of the cadmium was higher than that given in the literature with the exception of the Wieprza River in Poland and the Donghe
River in China $[10,29]$. The concentrations of lead in the waters of the research rivers was higher, but lower in southern Polish rivers $[15,18,19]$. The levels of zinc in the waters of the Parseta and the Radew were lower than for most rivers given in the literature. Only compared to Poland's southern rivers were levels of zinc higher $[15,18$, $19,20]$. The level of copper was higher than that given in the literature on the subject in Polish southern rivers and English, German, Turkish, and Chinese rivers [14, 15, 1820, 28-31].

This occurred despite the fact that both rivers carry water with relatively low concentrations of metals, which, at the same time, do not exceed the permitted levels (Tables 4 and 5).

Both studied rivers are characterized by similarity in terms of location. This entails a slight variation in the type of basin. Similar in character, a similar level of contamination in the Radew and Parseta catchments is confirmed by the results of the statistical analysis.

In order to assess the pollution of sediments with heavy metals, the geo-accumulation index $\left(I_{\text {geo }}\right)$ was calculated, which enabled bottom deposits to be classified [11]. The sediments sampled at all sites turned out to be free from pollution by copper, nickel, lead, zinc, and cadmium $\left(I_{\text {geo }}=0\right)$ (Tables 6 and 7). Only for cadmium was $I_{\text {geo }}$ occasionally higher -1 (sediments non-polluted to moderately polluted) [11]. According to the geo-chemical classification of Bojakowska and Sokołowska, all the analysed sediments belonged to class I [32]. In the case of a majority of the rivers in Western Pomerania (including the Radew and the Parseta) that were previously studied by Pokorny et al., the analysed bottom deposits also belonged to purity class $0[11,16]$.

A comparative analysis of the studied sediments in terms of nickel content in other examined rivers in Poland and rivers abroad indicates that nickel and zinc levels were 
Table 4. Different values of heavy metals in water $\left(\mathrm{mg} \cdot \mathrm{dm}^{-3}\right)$ and bottom sediments $\left(\mathrm{mg} \cdot \mathrm{kg}^{-1}\right)$ in rivers in Poland.

\begin{tabular}{|c|c|c|c|c|c|c|c|}
\hline Sampling area & Material & $\mathrm{Ni}$ & $\mathrm{Cd}$ & $\mathrm{Pb}$ & $\mathrm{Zn}$ & $\mathrm{Cu}$ & Reference \\
\hline Wieprz River & water & $0.01-0.02$ & $0.05-0.49$ & $0.03-0.30$ & $0.003-0.020$ & $0.38-2.20$ & {$[10]$} \\
\hline Lakes in Bory Tucholskie & water & $0.0008-0.0028$ & $<0.0024$ & $0.0002-0.318$ & $<0.0266$ & $0.0006-0.0053$ & {$[14]$} \\
\hline \multirow{2}{*}{ Ponds, southwest Poland } & water & 0.003-0.005 & $\mathrm{BDL}$ & $0.0002-0.0034$ & $0.002-0.091$ & $0.003-0.011$ & \multirow{2}{*}[15]{} \\
\hline & sediment & $2-16$ & $0.12-2.18$ & $3-20$ & $10-214$ & $2-09$ & \\
\hline $\begin{array}{l}\text { Parseta, Radew and other } \\
\text { rivers, north Poland }\end{array}$ & sediment & $1.39-14.39$ & $0.04-1.51$ & $4.80-18.25$ & $5.23-47.12$ & $0.67-11.46$ & {$[16]$} \\
\hline \multirow{2}{*}{$\begin{array}{l}\text { Czeska Struga Stream, } \\
\text { Karkonosze Mountains }\end{array}$} & water & $0.006-0.015$ & $0.003-0.004$ & $0.034-0.112$ & $0.041-0.049$ & $0.008-0.013$ & \multirow{2}{*}{ [17] } \\
\hline & sediment & $6-11$ & $0.88-1.49$ & $36-64$ & $47-122$ & $8-11$ & \\
\hline Kozi Brod River, south Poland & water & BDL & 0.0003-0.0009 & $<0.001$ & $0.103-0.340$ & $0.0004-0.0016$ & [18] \\
\hline \multirow{2}{*}{ River of the Odra catchment } & water & $0.0005-0.0063$ & $0.0002-0.0004$ & $<0.0004$ & $0.146-0.189$ & $0.001-0.017$ & \multirow{2}{*}{ [19] } \\
\hline & sediment & $<350$ & $8-42$ & $61-426$ & $10-811$ & $4-361$ & \\
\hline \multirow{2}{*}{ Southwest rivers of Poland } & water & $0.003-0.023$ & $<0.0002$ & $0.003-0.280$ & $0.011-0.046$ & $0.011-0.059$ & \multirow{2}{*}{ [20] } \\
\hline & sediment & $5.8-34.4$ & $0.1-0.44$ & $21-274$ & $40-152$ & $9-576$ & \\
\hline
\end{tabular}

BDL - below detection limit

Table 5. Different values of heavy metals in water $\left(\mathrm{mg} \cdot \mathrm{dm}^{-3}\right)$ and bottom sediments $\left(\mathrm{mg} \cdot \mathrm{kg}^{-1}\right)$ of rivers in Europe and around the world.

\begin{tabular}{|c|c|c|c|c|c|c|c|}
\hline Sampling area & Material & $\mathrm{Ni}$ & $\mathrm{Cd}$ & $\mathrm{Pb}$ & $\mathrm{Zn}$ & $\mathrm{Cu}$ & Reference \\
\hline \multirow{2}{*}{$\begin{array}{l}\text { Imera Meridionale river, } \\
\text { Sicily, Italy }\end{array}$} & water & 0.108 & 0.0004 & 0.0004 & 0.0004 & 0.084 & \multirow{2}{*}{ [21] } \\
\hline & sediment & 29.14 & 0.66 & 2.67 & 9.69 & 10.60 & \\
\hline $\begin{array}{l}\text { Streams, southeast } \\
\text { Queensland, Austalia }\end{array}$ & sediment & n.d. & $<3$ & $13-169$ & $29-675$ & $5-69$ & {$[22]$} \\
\hline Seine River, France & sediment & $5-20$ & 0.010 & $5-278$ & $26-536$ & $10-172$ & {$[23]$} \\
\hline \multirow{2}{*}{ Gomti River, India } & water & $0.007-0.186$ & $\mathrm{BDL}$ & $0.002-0.086$ & $0.022-0.160$ & $0.00-0.045$ & \multirow{2}{*}[24]{} \\
\hline & sediment & $5-65$ & $0.5-20$ & $5-111$ & $11-249$ & $3-118$ & \\
\hline \multirow{2}{*}{ Rivers, southeast Brasil } & water & $0.010-0.106$ & $\mathrm{BDL}$ & 0.010 & $0.0075-0.355$ & $0.0001-0.094$ & \multirow{2}{*}[25]{} \\
\hline & sediment & $15.6-46.0$ & $<0.1$ & $5-49$ & $53.2-1490$ & $18.8-54.5$ & \\
\hline Streams, southwestern USA & sediment & n.d. & $<7$ & $17-63$ & $71-683$ & $16-49$ & {$[26]$} \\
\hline \multirow{2}{*}{ Tsurumi River, Japan } & water & $0.026-0.078$ & $0.001-0.005$ & $0.004-0.007$ & $0.226-0.239$ & $0.470-0.543$ & \multirow{2}{*}[27]{} \\
\hline & sediment & $55-59$ & $1.6-1.7$ & $43-55$ & $322-368$ & $99-130$ & \\
\hline Thames River, England & water & $0.002-0.011$ & $<0.004$ & $<0.004$ & $0.002-0.295$ & $0.005-0.010$ & [28] \\
\hline \multirow{2}{*}{ Donghe River, China } & water & n.d. & $0.001-0.074$ & $0.003-0.03$ & $0.051-1.290$ & $0.014-0.025$ & \multirow{2}{*}[29]{} \\
\hline & sediment & n.d. & $1-642$ & $74-13900$ & $23-1080$ & $27-452$ & \\
\hline \multirow{2}{*}{$\begin{array}{l}\text { Rivers in Ore Mountains, } \\
\text { Germany }\end{array}$} & sediment & 50 & 0.23 & 10 & 70 & 45 & \multirow{2}{*}[30]{} \\
\hline & water & $<0.0085$ & $<0.001$ & $0.001-0.005$ & $0.004-0.008$ & $0.005-0.015$ & \\
\hline Kehli Stream, Turkey & water & $<0.008$ & $<0.003$ & $<0.005$ & $<0.271$ & $<0.008$ & [31] \\
\hline
\end{tabular}

BDL - below detection limit,

n.d. - no data 
Table 6. The values of geo-accumulation index $\left(I_{\text {geo }}\right)$ of metals in Parseta sediments and the purity standard of sediments [11].

\begin{tabular}{|c|c|c|c|c|c|c|c|c|c|c|}
\hline \multirow{2}{*}{$\begin{array}{c}\text { Sites } \\
\text { (number) }\end{array}$} & \multicolumn{3}{|c|}{$\mathrm{Ni}$} & \multicolumn{2}{c|}{$\mathrm{Cd}$} & \multicolumn{3}{c|}{$\mathrm{Pb}$} & \multicolumn{2}{c|}{$\mathrm{Cu}$} \\
\cline { 2 - 12 } & 2012 & 2013 & 2012 & 2013 & 2012 & 2013 & 2012 & 2013 & 2012 & 2013 \\
\hline 1 & -1.57 & -1.46 & -4.88 & -1.62 & -0.58 & -1.27 & -1.40 & -2.96 & -1.43 & -3.20 \\
\hline 2 & -2.16 & -0.67 & -6.12 & -0.58 & -2.56 & -0.84 & -3.88 & -2.13 & -3.76 & -2.00 \\
\hline 3 & -2.46 & $\mathbf{0 . 0 1}$ & -7.12 & -0.10 & -2.32 & -0.17 & -3.74 & -1.22 & -4.26 & -0.29 \\
\hline 4 & -2.10 & -1.46 & -3.21 & -0.97 & -1.86 & -1.38 & -3.22 & -3.03 & -3.66 & -3.19 \\
\hline 5 & -2.26 & -0.55 & -6.76 & -1.23 & -1.85 & -0.80 & -3.33 & -2.17 & -3.68 & -1.61 \\
\hline 6 & -1.82 & -1.75 & -3.88 & -1.86 & -1.67 & -1.63 & -3.46 & -2.85 & -3.56 & -3.18 \\
\hline 7 & -1.98 & -1.25 & -4.01 & -1.91 & -1.67 & -1.70 & -3.51 & -2.82 & -3.29 & -1.79 \\
\hline 8 & -1.70 & -1.14 & -2.65 & -1.34 & -1.62 & -1.46 & -3.27 & -2.64 & -1.99 & -2.69 \\
\hline 9 & -1.82 & -0.85 & -3.04 & -0.57 & -1.45 & $\mathbf{0 . 2 3}$ & -2.19 & -2.15 & -3.03 & -0.29 \\
\hline
\end{tabular}

Not bolded - Class 0, Bolded - Class 1

Table 7. The values of geo-accumulation index $\left(I_{\text {geo }}\right)$ of metals in Radew sediments and the purity standard of sediments [11].

\begin{tabular}{|c|c|c|c|c|c|c|c|c|c|c|}
\hline \multirow{2}{*}{$\begin{array}{c}\text { Sites } \\
\text { (number) }\end{array}$} & \multicolumn{3}{|c|}{$\mathrm{Ni}$} & \multicolumn{2}{c|}{$\mathrm{Cd}$} & \multicolumn{3}{c|}{$\mathrm{Pb}$} & \multicolumn{2}{c|}{$\mathrm{Cu}$} \\
\cline { 2 - 11 } & 2012 & 2013 & 2012 & 2013 & 2012 & 2013 & 2012 & 2013 & 2012 & 2013 \\
\hline 1 & -3.09 & -1.54 & -6.92 & -1.94 & -2.24 & -1.76 & -4.28 & -1.99 & -4.72 & -2.24 \\
\hline 2 & -2.15 & -1.61 & -6.79 & -1.80 & -1.30 & -1.72 & -2.82 & -3.05 & -3.80 & -2.76 \\
\hline 3 & -0.85 & -1.48 & -2.78 & -1.19 & -1.40 & -1.54 & -2.62 & -3.05 & -4.50 & -3.51 \\
\hline 4 & -2.64 & -0.13 & -3.03 & $\mathbf{0 . 4 2}$ & -0.85 & -0.09 & -1.47 & -0.51 & -0.91 & -0.17 \\
\hline 5 & -1.42 & -0.41 & -8.29 & $\mathbf{0 . 3 9}$ & -1.74 & -0.82 & -2.85 & -0.73 & -2.25 & -0.70 \\
\hline 6 & -2.22 & -0.94 & -8.17 & -1.41 & -1.68 & -1.07 & -4.25 & -2.61 & -5.25 & -2.00 \\
\hline 7 & -3.00 & -0.42 & -7.38 & -0.25 & -2.03 & -0.81 & -3.85 & -2.26 & -3.67 & -0.53 \\
\hline 8 & -1.87 & 0.00 & -6.59 & -0.51 & -1.03 & -0.52 & -2.50 & -1.36 & -1.75 & -0.09 \\
\hline 9 & -3.75 & -2.05 & -7.29 & -1.05 & -2.18 & -1.68 & -4.25 & -3.57 & -5.68 & -3.90 \\
\hline
\end{tabular}

Not bolded - Class 0, Bolded - Class 1

lower in the Parseta and Radew. Copper content in researched rivers was lower than those described in the literature from Europe and the other side of the world [21-31]. But a comparative analysis of the copper content in Polish rivers shows higher levels in the Radew and Parseta. The contents of cadmium in the sediments of the Parseta and the Radew were lower than that given in the literature on the subject with the exception of rivers of Italy, France, and Brazil [21, 23, 25]. Lead content was higher in Polish rivers than in the Radew and Parseta.

There was a higher level of copper noted in Radew and Parseta sediments than abroad, with the exception of southern Polish rivers and also rivers in France, India, Brazil, and Japan [17, 19, 20, 23-25, 27].

A comparison of the obtained results in the literature on the subject shows that metal contents in Radew and Parseta waters were higher, for example, than in rivers draining the Karkonosze Mountains (southern Poland), which are under the influence of local industrial operations $[17,18,20,30$, $33,34]$. This, however, was not reflected in bottom sediment samples.

In comparison with other examined surface water reservoirs in western Poland that are also under the influence of industrial operations (metallurgical, food, pharmaceutical, chemical industries), only nickel contents were lower in the Parseta and the Radew [35]. The concentrations of heavy metals in the bottom sediments from that area were decidedly higher than in the case of rivers in Western Pomerania.

Water from the Wieprz River, examined by Bojakowska et al., which flows through a region where natural gas, petroleum, and hard coal are mined, was characterised by cadmium and lead contents higher than those in rivers in the coastal belt (the Radew and the Parseta), but also with lower contents of copper, nickel, and zinc [10]. A similar phenomenon has been noted in the case of lake waters under the influence of a copper smelter (Lubin, Poland) [33]. 
Significantly higher bottom sediment pollution with heavy metals rates were recorded for surface waters strongly influenced by urbanised industrial areas, for instance petroleum refineries in Greece, India, Cameroon, and Turkey [35-39]. Higher metal contents in sediments were also observed in the Gomti River in the Ganges catchment in India, with low metal concentrations in water [24]. River waters in areas neighbouring kaolinite mines in Brazil also contained higher amounts of copper and zinc, but lower amounts of nickel and lead than those in the Radew and the Parseta. Metal contents in bottom sediments there significantly exceeded the values recorded for Polish rivers [25]. However, in rivers subject to strong pollution, heavy metal contents in sediments do not necessarily have to be very high - this is attested to by rivers in Cameroon, France, England, and Turkey [23, 28, 35].

Metal contents in bottom sediments of both the Radew and the Parseta changed, depending on how far downstream samples were taken. The sites closest to the Petroleum and Natural Gas Mine at Karlino had the highest levels of all the metals studied when compared with samples taken above and below such locations. Although spot influence of pollution was visible, sediments of the Parseta and the Radew further down the stream were significantly cleaner. The selfpurification process regards principally the Parseta, as the Radew ends its course below Karlino, at Bialogard.

\section{Conclusions}

In terms of their physico-chemical composition, the tested waters of the Parseta and the Radew can be described as slightly polluted. Zinc and copper concentrations place the waters in purity class I, but the contents of cadmium, lead, and nickel exceeded the Proposed Environmental Quality Standards for Priority Substances.

In terms of copper, nickel, zinc, and cadmium, the studied sediments were not polluted, and the geo-chemical index values were within class 0 (non-polluted). Accumulation rates for metals in sediments can be ordered as follows: $\mathrm{Cd}<\mathrm{Ni}<\mathrm{Pb}<\mathrm{Cu}<\mathrm{Zn}$.

The studied parameters changed according to how far downstream samples were taken. The sites on the Radew and the Parseta closest to the petroleum and natural gas mine at Karlino had the highest levels of all the metals studied. However, further down the stream the values fell and the river water self-purification process was evident. It is encouraging that, despite a clear impact of the presence of the mine on the examined water quality, the aquatic environment seems not only able to absorb pollutants, but also to recover over a relatively short section of the rivers.

\section{Acknowledgements}

Publication supported by Wroclaw Centre of Biotechnology, programme the Leading National Research Centre (KNOW) for years 2014-2018.

\section{References}

1. Report on the state of the environment in Western Pomerania in 2006-2007. Environ. Monit. Library. Szczecin, 2008 [In Polish].

2. PN-90/C-0454/01 - Determination of $\mathrm{pH}$ of water and wastewater for electrolytic conductivity of $10 \mathrm{mS} / \mathrm{cm}^{3}$ and above by electrometric, 2001 [In Polish].

3. PN-EN 27888:1999 - Determination of electrolytic conductivity, 1999 [In Polish].

4. PN-EN ISO 9963-A+Ap: 2004 - Determination of alkalinity to methyl orange, 2004.

5. PN-ISO 6058:1999 - Determination of calcium in water, 1999 [In Polish].

6. PN-ISO 6059:1999 - Determination of total hardness in water, 1999 [In Polish].

7. PN-ISO 9297:1994 - Determination of the chloride content in the water, 1994 [In Polish].

8. PB-10/I - Test procedure. Analytical methods Company VARIAN, 1998.

9. JEZIERSKA B., WITESKA M. Metal toxicity to fish. Wyd. Akademii Podlaskiej. Siedlce, 2001.

10. BOJAKOWSKA I., GLIWICZ T., KOZŁOWSKA O., SZYBORSKA-KASZYCKA J. Geochemical characteristics of the Wieprz River water. Górnictwo i Geologia. 5, (4), 51, 2010 [In Polish with English abstract].

11. MÜLLER G. Heavy metals in the sediments of the Rhine. Changes since 1971. Umschau Wiss. Techn, 79, 778, 1979 [In German].

12. European Parliament and of the Council 2008/105/EC of $16^{\text {th }}$ December 2008.

13. Journal of the Laws No. 257, item 1545 of $9^{\text {th }}$ November 2011 [In Polish].

14. GWOŹDZIŃSKI K., MAZUR J., PIENIĄŻEK A. Concentrations of metals in water of unmonitored lakes near a landscape park. Pol. J. Environ. Stud. 23, 4, 1317, 2014.

15. KLINK A., MACIOŁ A., WISŁOCKA M., KRAWCZYK J. Metal accumulation and distribution in the organs of Typhalatifolia L. (cattail) and their potential use in bioindication. Limnologica. 43, 164, 2013.

16. POKORNY P. SENZE M., DOBICKI W., KOWALSKAGÓRALSKA M., POLECHOŃSKI R. Geochemical assessment of Western Pomerania watercourses. Przem. Chem. 92, (9), 1768, 2013 [In Polish with English abstract].

17. SAMECKA-CYMERMAN A., KEMPERS A. J. Bioindication of heavy metals by Mimulus guttatus from the Czeska Struga Stream in the Karkonosze Mountains, Poland. B. Environ. Contam. Tox. 63, 65, 1999.

18. SAMECKA-CYMERMAN A., KEMPERS A. J. Bioindication of heavy metals with aquatic macrophytes: The case of a stream polluted with power plant sewages in Poland. J. Toxicol. Env. Heal A. 62, 57, 2001.

19. SAMECKA-CYMERMAN A., KEMPERS A. J. Biomonitoring of water pollution with Elodea canadensis. A case study of three small Polish rivers with different levels of pollution. Water Air Soil Poll. 145, 139, 2003.

20. SAMECKA-CYMERMAN A., KOLON K., KEMPERS A. J. A comparison of native and transplanted Frontalis antipyretica Hedw. as biomonitors of water polluted with heavy metals. Sci. Total Environ. 341, 97, 2005.

21. BONNANO G., LO GIUDICE R. Heavy metal bioaccumulation by the organs of Phragmites australis (common reed) and their potential use as contamination indicators. Ecol. Indic. 10, 639, 2010. 
22. CARDWELL A.J., HAWKER D.W, GREENWAY M. Metal accumulation in aquatic macrophytes from southeast Queensland, Australia. Chemosphere. 48, 653, 2002.

23. CARPENTIER S., MOILLERON R., BELTRAN C., HERVE D., THEVENOT D. Quality of dredged material in the river Seine basin (France). II. Micropollutants. Sci. Total Environ. 299, 57, 2002.

24. GAUR V.K., GUPTA S.K., PANDEY S.D., GOPAL K., MISHRA V. Distribution of heavy metals in sediment and water of river Gomti. Environ. Monit. Assess. 102, 419, 2005.

25. JORDÃO C.P., PEREIRA M.G., PEREIRA J.L. Metal contamination of river waters and sediments from effluents of kaolin processing in Brasil. Water Air Soil Poll. 140, 119, 2002.

26. MARTINEZ E.A., SHU-NYAMBOLI C. Determination of selected heavy metal concentrations and distribution in a southwestern stream using macrophytes. Ecotox. Environ. Safe. 74, 1504, 2011.

27. MOHIUDDIN K.M., OTOMO K., OGAWA Y., SHIKAZONO N. Seasonal and spatial distribution of trace elements in the water and sediments of the Tsurumi River in Japan. Environ. Monit Assess. 184, 265, 2012.

28. NEAL C., WILLIAMS R.J., NEAL M., BHARDWAJ L.C., WICKHAM H., HARROW M., HILL L.K. The water quality of the River Thames at a rural site downstream of Oxford. Sci. Total Environ. 251/252, 441, 2000.

29. PENG K., LUO C., LOU L., LI X., SHEN Z. Bioaccumulation of heavy metals by the aquatic plants Potamogeton pectinatus L. and Potamogeton malaianus Miq. and their potential use for contamination indicators and in wastewater treatment. Sci. Total Environ. 192, 22, 2008.

30. SAMECKA-CYMERMAN A., KOLON K., KEMPERS A J. Heavy metals in Aquatic Bryophytes from the Ore Mountains (Germany). Ecotox. Environ. Safe. 52, 203, 2002.
31. SASMAZ A., OBEK E., HASAR H. The accumulation of heavy metals in Typha latifolia L. grown in a stream carrying secondary effluent. Ecol. Eng. 33, 278, 2008.

32. BOJAKOWSKA I., SOKOŁOWSKA G. Geochemical cleanliness class of bottom sediments. Prz. Geol. 46, (1), 49, 1998 [In Polish].

33. SAMECKA-CYMERMAN A., KEMPERS A. J. Toxic metals in aquatic plants surviving in surface water polluted by copper mining industry. Ecotox. Environ. Safe. 59, 64, 2004.

34. SAMECKA-CYMERMAN A., KEMPERS A.J. Concentration of heavy metals and plant nutrients in water, sediments and aquatic macrophytes of antropogenic lakes (former open cut brown coal mines) differing in stage of acidification. Sci. Total Environ. 281, 87, 2001.

35. AKBULUT N.E., TUNCER A.M. Accumulation of heavy metals with water quality parameters in Kizilirmak River Basin (Delice River) in Turkey. Environ. Monit. Assess. 173, 387, 2011

36. BARUAH N.K., KOTOKY P., BHATTACHARYYA K.G, BORAH G.C. Metal speciation in Jhanji River sediments. Sci. Total Environ. 193, 1, 1996.

37. EKENGELE N.L., MYUNG C.J., OMBOLO A., NGOUNOU N., EKODECK G., MBONE L. Metals pollution in freshly deposited sediments from river Mingoa, main tributary to the municipal lake of Yaounde, Cameroon. Geosci. J. 12, (4), 337, 2008.

38. HAHLADAKIS J., SMARAGDAKI E., VASILAKI G., GIDARAKOWS E. Use of sediment quality guidelines and pollution indicators for the assessment of heavy metal and PAH contamination in Greek surficial sea and lake sediments. Environ. Monit. Assess. 185, 2843, 2013.

39. HEJABI A.T., BASAVARAJAPPA H.T., KARBASSI A.R., MONAVARI S.M. Heavy metal pollution in water and sediments in the Kabini River, Larnataka, India. Environ. Monit. Assess. 182, 1, 2011. 
